\title{
Recenzja \\ Przemysław Osóbka, Parlament Bośni i Hercegowiny, Wydawnictwo Sejmowe, Warszawa 2010, ss. 44
}

Nakładem Wydawnictwa Sejmowego ukazała się kolejna pozycja z serii wydawniczej „Parlamenty”, a mianowicie Parlament Bośni i Hercegowiny autorstwa Przemysława Osóbki. Powinna to być o tyle interesująca informacja, że wciąż w polskiej literaturze wyraźny brak opracowań dotyczących Bośni i Hercegowiny, które odnosiłyby się do tematyki innej niż wojenna. Wiele bowiem książek czy artykułów w czasopismach jest poświęconych kwestii działań zbrojnych lub czystek etnicznych, a nieliczne są przykłady publikacji, które poświęcone są problematyce ustrojowej, skądinąd niezwykle interesującej. Do wyjątków pod tym względem można przede wszystkim zaliczyć monografię Europejski protektorat? Bośnia i Hercegowina w perspektywie środkowoeuropejskiej pod redakcją M. Gniazdowskiego (Warszawa 2008) czy też np. pojedyncze artykuły w „Przeglądzie Sejmowym” lub „Roczniku Nauk Politycznych”. Teraz można do nich zaliczyć również pracę Przemysława Osóbki.

Omawianej pozycji bez wątpienia nie można zaliczyć do grona szczególnie obszernych, jest to jednak przyjęty standard w tej serii wydawniczej. Podzielona została na trzynaście części, które odpowiadają poszczególnym zagadnieniom, takim jak: rys historyczny parlamentaryzmu bośniackiego, konstytucyjna pozycja parlamentu, prawo parlamentarne, struktura parlamentu, system wyborczy, deputowani, grupy parlamentarne, organizacja wewnętrzna, funkcjonowanie parlamentu, funkcja ustawodawcza, uchwalenie budżetu, parlament a inne organy państwowe oraz organy pomocnicze. Ponadto Autor opracował w formie graficznej trzy aneksy, które w czytelny sposób ukazują wyniki wyborów parlamentarnych, system organów państwowych oraz procedurę ustawodawczą. Taki układ pracy uznać należy za logiczny i prawidłowy.

Wypada zgodzić się z Autorem, że „Problemy, z którymi boryka się Bośnia i Hercegowina, znajdują swoje odzwierciedlenie w kształcie jej systemu 
politycznego oraz w mechanizmach nim rządzących" (s. 5). Tym bardziej trzeba docenić wysiłek włożony w analizę obowiązujących w tym państwie rozwiązań, narzuconych zresztą w listopadzie 1995 r. przez wspólnotę międzynarodową w ramach porozumienia pokojowego z Dayton. Brak jest bowiem w Europie drugiego kraju, w którym za pomocą równie skomplikowanego porządku konstytucyjnego próbowano by wprowadzić trwały pokój między mocno zwaśnione narody - w tym przypadku Bośniaków, Serbów i Chorwatów. Ofiarą tego systemu stał się także organ legislatury - Skupština Parlamentarna Bośni i Hercegowiny, składająca się z Izby Reprezentantów ${ }^{1}$ oraz Izby Narodów.

Autor starając się przedstawić możliwie dokładnie genezę obecnych rozwiązań, sięga do historii, ukazując kształtowanie się parlamentaryzmu na tym obszarze. Podkreśla rolę pierwszego Saboru Bośniackiego, powołanego jeszcze przez władze austro-węgierskie na początku XX w. Już wtedy skład parlamentu stanowił odwzorowanie składu religijnego społeczeństwa (s. 8). W następnych latach ten podział konfesyjny na muzułmanów, prawosławnych i katolików przerodził się w podział narodowy, co znalazło odbicie we wszystkich organach władzy. To zjawisko jest szczególnie widoczne w obecnie obowiązującym porządku prawnym, co często podkreśla autor (s. 11). Przy omawianiu procedury głosowania (s. 26), strukturze komisji parlamentarnych (s. 23-24), a przede wszystkim przy analizie prawa wyborczego (s. 16-19) wyraźne są cele, które przyświecały ustrojodawcy - zapewnienie równouprawnienia Bośniaków, Serbów i Chorwatów nawet kosztem sprawnego funkcjonowania parlamentu czy też naruszenia niektórych demokratycznych praw przedstawicieli innych narodów. Z podkreśleniem dominującej pozycji narodów konstytutywnych można się także spotkać przy dokonanej przez autora analizie składu izby wyższej parlamentu - Izby Narodów, gdzie nie mogą zasiadać przedstawiciele innych narodów niż wymienione powyżej, jak też przy omówieniu wymogów dotyczących kworum, w którym każdy z tych narodów musi mieć odpowiedni udział (s. 25). Przemysław Osóbka zwraca również uwagę na procedurę ochrony tzw. „żywotnych interesów każdego z trzech narodów" (s. 27), która to może doprowadzić do paraliżu prac parlamentarnych.

Po przeprowadzonej analizie pozycji ustrojowej parlamentu oraz jego zakresu kompetencji i relacji z innymi organami władzy (kolegialnym Prezy-

\footnotetext{
1 W literaturze można też znaleźć określenie „Izba Przedstawicielska”.
} 
dium, Radą Ministrów i Sądem Konstytucyjnym) autor słusznie zauważa, że rola Skupština Parlamentarnej w systemie politycznym jest w znacznym stopniu ograniczona. Na taki stan rzeczy wpływają zarówno prerogatywy 3-osobowego Prezydium Bośni i Hercegowiny (składającego się z Bośniaka, Serba i Chorwata), jak i szerokie kompetencje parlamentów dwóch jednostek składowych - Federacji Bośni i Hercegowiny oraz Republiki Serbskiej. Nie można zapomnieć także o tym, że Bośnia i Hercegowina stała się de facto protektoratem w następstwie działalności Urzędu Wysokiego Przedstawiciela (OHR), będącego reprezentantem wspólnoty międzynarodowej. Może on - na mocy nadanych w 1997 r. w Bonn kompetencji - dymisjonować osoby zajmujące nawet najwyższe stanowiska państwowe (w tym w Prezydium), jeśli tylko istnieje podejrzenie działania na szkodę procesu pokojowego (s. 13). Jest także w stanie narzucać ustawy, jeśli parlament nie potrafi samodzielnie podjąć decyzji ${ }^{2}$. Autor słusznie zauważa, że - mimo kontrowersyjności samej idei istnienia organu - podejmowane przez OHR działania i presja z jego strony wpłynęły na poprawę funkcjonalności organów państwowych (s. 13).

Doceniając trud włożony przez autora w przeanalizowanie rozwiązań ustrojowych dotyczących struktury, pozycji oraz roli Skupštiny Parlamentarnej Bośni i Hercegowiny, należy zwrócić uwagę na kilka błędów i niedociągnięć. Przede wszystkim zwraca uwagę fakt pominięcia kilku niezwykle istotnych pozycji literaturowych. Wśród nich rzuca się w oczy brak dwóch bodajże najważniejszych w ostatnim okresie książek: fundamentalnej dla zagadnień parlamentaryzmu pracy Proces odlučivanja u Parlamentarnoj Skupštini Bosne i Hercegovine pod redakcją I. Marić (Sarajevo 2009) oraz Uvod u politički sistem Bosne i Hercegovine - izabrani aspekti pod redakcją S. Gavricia, D. Banovicia i C. Krause (Sarajevo 2009). Niestety, zdarzają się też w tekście błędy merytoryczne, niektóre dość poważne. Zaliczyć do nich trzeba przedstawienie sposobu wyłaniania składu Izby Reprezentantów - autor podaje, że z terenu Federacji wybiera się tylko przedstawicieli Bośniaków i Chorwatów, a z Republiki tylko Serbów (s. 15), gdy w rzeczywistości nie ma takiego ograniczenia (w przeciwieństwie do Izby Narodów). Tak samo należy potraktować sformułowanie, że w obu izbach decyzje zapadają zwy-

2 Dla porównania - w latach 1997-2007 Wysoki Przedstawiciel wydał aż 112 ustaw wobec 279 uchwalonych przez Skupštinę. 
kłą większością głosów, podczas gdy jest to sytuacja wyjątkowa ${ }^{3}$. Niefortunne jest też częste używanie przez autora określenia „rząd” w odniesieniu do Rady Ministrów. W przeciwieństwie do np. polskiej tradycji, taka wymienność nie jest przyjęta w Bośni i Hercegowinie, szczególnie w analizach poświęconych prawu konstytucyjnemu - Rada Ministrów traktowana jest organ obdarzony skromniejszym zakresem kompetencji.

Wreszcie wypada zwrócić uwagę na brak konsekwencji autora w przytaczaniu źródeł będących pracami pod redakcją - w niektórych przypadkach odwołuje się tylko do redaktorów, bez podania tytułu rozdziału i jego autora (s. 8-9 i 30, R. Grabowski, S. Grabowska, Zasady zmiany konstytucji w państwach europejskich, Warszawa 2008, s. 59), a w innych podaje pełną i prawidłową notkę bibliograficzną (s. 13, L. Hladký, Dwanaście lat po Dayton - rzeczywistość i iluzje, [w:] M. Gniazdowski (red.) Europejski protektorat? Bośnia i Hercegowina w pespektywie środkowoeuropejskiej, Warszawa 2008, s. 21$-22)$.

Tym niemniej, mimo wskazanych powyżej uchybień, recenzowana praca bez wątpienia stanowi interesującą propozycję wydawniczą. Przedstawia mało znane oblicze Bośni i Hercegowiny, czyli jej niezwykle skomplikowany i niespotykany gdzie indziej system polityczny, ukazany przez pryzmat organu władzy ustawodawczej.

Krzysztof Krysieniel (Wyższa Szkoła Bankowa w Poznaniu)

3 Por. K. Trnka, Ustavno i poslovničko pozicioniranje procesa odlučivanja u Parlamentarnoj skupštini BiH, [w:] Proces odlučivanja u Parlamentarnoj Skupštini Bosne i Hercegovine, pod red. I. Marić, Sarajevo 2009, s. 43-44. 